\title{
A descriptive survey to assess the level of stress related to virtual teaching among Nursing faculties during COVID- 19 Pandemic at selected Nursing colleges of North- East India.
}

\author{
Khumukcham Anupama Devi', Athira B ${ }^{2}$, Priyanka Elizabeth Thomas ${ }^{3}$, Anjali Sancha ${ }^{4}$, Nikita \\ Kumari ${ }^{5}$, Pallavi Jyoti ${ }^{6}$, Pooja Karanwal ${ }^{7}$,Pooja Kumari ${ }^{8}$, Prachi Priya ${ }^{9}$, Prachi Sah ${ }^{10}$, \\ Pratima Kumari ${ }^{11}$, Preeti ${ }^{12}$, Prerna, Princi ${ }^{13}$, Anand ${ }^{14}$, and Priyanka ${ }^{15}$ \\ 3.1. Tutor, College of Nursing, AIIMS Patna.khanupama28@gmailcom \\ 4.2. Tutor, College of Nursing, AIIMS Patna.athirasuni127@gmail.com \\ 5.3. Tutor, College of Nursing, AIIMS Patna. \\ ${ }^{6.4}$.Tutor, College of Nursing, AIIMS Patna \\ 7.5 -15. Nursing Officers of AIIMS Patna \\ DOI: 10.29322/IJSRP.11.09.2021.p11729 \\ http://dx.doi.org/10.29322/IJSRP.11.09.2021.p11729
}

\begin{abstract}
The Research Project attempted to assess the stress level related to virtual teaching among Nursing faculties during Covid19 Pandemic in selected Nursing Colleges of North-East India. The objectives of the study were to assess the stress level related to virtual teaching and to find the association between stress level and selected demographic variables. Qualitative approach and Non-Experimental Descriptive Survey Research Design were used. Nursing Colleges of North-East India was taken as target population from which 56 samples were collected. Data was collected by sending online questionnaire (MCQs) through email. Data Analysis was done by using descriptive and inferential statistics. Results showed that $14.3 \%$ Nursing Faculties suffered from low stress, $80.4 \%$ suffered from moderate stress and $5.4 \%$ suffered from high stress i.e., most of the Nursing faculties suffered moderate stress and it also revealed that there was no association between stress and the selected socio- demographic variables i.e., age, marital status, qualification, total year of employment, salary per month, how long they are using virtual teaching, previous experiences in virtual teaching and duration of classes taken in a week.
\end{abstract}

Index Terms- Stress level, Virtual-Teaching, Nursing Faculties, COVID-19 Pandemic

\section{INTRODUCTION}

$\mathrm{C}$ ovid 19 is one of those pandemics that hits the whole world in a highly devastating way. It started from one city of China in December 2019, but in a short span of time, it covered almost all over the world. On February 11, 2020 WHO changed the name of this SARS Cov 2 to Covid -19. The Novel Corona causing calamity by droplets. Till January 2020, 15 countries of the world had reported the contagious spread of this novel corona virus. The confirmed cases reported globally by WHO $1 \mathrm{ST}$ are 6065 till

This publication is licensed under Creative Commons Attribution CC BY.

http://dx.doi.org/10.29322/IJSRP.11.09.2021.p11729
January across the different parts of the world, along with China 15 other countries were affected.

In India, the first case of Covid 19 was reported on January 30, 2020 in Kerala. The Covid-19 was spreading contagiously and quickly started affecting most of the human population across India. WHO and by subsequent following confirmed cases and death over the world has declared the Covid -19 world pandemic on March 11,2020 (4) to maintain social distancing and to break the chain of spread of the Covid-19. India took very decisive steps to deal with Covid-19 pandemic, in this order total lockdown was imposed by the Government of India from March 25,2020, with the slogan of "stay home, stay safe".

Although the step of lockdown was challenging and can be riskier for different areas including jobs of people, economy, education system and health care system. It was imposed strictly. The schools and colleges were shut down for uncertain period in order to contain the spread of the Covid -19 pandemic.

The UNESCO report estimates that corona virus pandemic will adversely impact over 290.5 million students across 22 countries till 4th of March. The UNESCO estimate that about 32 crore students are affected in India including those in schools and colleges. (5)

The teaching process was halted due to lockdown all the conventional mode of education was blocked and need to look for another prompt and easy method of teaching Covid-19 has forced to switch e-learning method of education in order to control the infection. The Virtual model of teaching has replaced this conventional mode of teaching everywhere in India in all the colleges and schools of India.

Method of education delivery using an online platform like Google Classroom, Google meet, Zoom, edX , Duolingo etc. Virtual reality technology as a new teaching media, has been widely used to teach in colleges and universities in foreign countries but became a necessity for all in Covid -19 era. The policy of transferring learning activities of school and colleges to home has implications for changing the learning model from face- 
to-face media to online. They utilize non paid applications such as Google classroom, zoom, Google meet, Jio meet and other facilities. (6) The technology is not new for us but using it effectively is still a learning process. The sudden change in the method of teaching has created huge chaos in students as well as teachers lives \& possible of health issues. (7) Teaching was often listed as one of the most stressful professions and being a nursing or medical faculty triggers its own unique challenges. Response to Covid-19 pandemic and virtual teaching has created a long list of stressors for teachers including less knowledge about online teaching, lack of interactions with students, long monotonous classes, power outages and lack of internet facility difficulty in conduction of exams, assessment and practical classes and many more.

Stress is "Non-specific response of the body to any kind of demand made upon it'. Stress is the arousal of mind and body in response to demands made upon them. (8) Stress is an unavoidable experience resulting from the complex interactions between an individual and his or her environment. Stress occurs when individual resources are insufficient to cope with situational demands and pressures. Stress is a subjective experience that is more likely to arise in some situations than others. In addition, some individuals can be more prone to stress than others. Overall, stress can undermine the achievement of goals, both for individuals and organisations. (9)

The sudden change from a conventional method of teaching to virtual teaching affects teachers along with the students. But there are few studies about due to virtual teaching and other factors associated with virtual teaching and the teachers, which will indirectly help to improve their health by knowing about the measures to reduce the stress and causing factors because of after all'. So this study was done to assess the level of stress related to virtual teaching among Nursing faculties during Covid-19 Pandemic at selected Nursing colleges of North-East India.',

\section{OBJECTIVES}

1. To assess the stress level related to virtual teaching

2. To find the association between stress levels in selected demographic variables of Nursing Faculties.

\section{OPERATIONAL DEFINITION}

Virtual teaching: Method of education delivery using online teaching platforms like Google classroom, Google meet, Zoom, edX, Duolingo etc.

Stress: Stress is the response of our body and mind to any physical or psychological stressors.

Nursing faculty: The individual who has been completed their respective qualifications and recruited in Nursing College as Professor, Associate Professor, Assistant Professor/ Lecturer, clinical instructor or nursing tutor to teach and professionally train the students of GNM, B.Sc. Nursing M.Sc. Nursing, M.Phil., PhD

Covid 19 Pandemic: COVID 19 is a disease caused by a new strain of Corona virus.' CO' stand for corona 'VI' stands for virus and ' $\mathrm{D}$ ' stand for disease. Formerly this disease was referred to as ' 2019 novel Coronavirus or 2019 -n Co V'. the virus emerged in December 2019 and was first discovered in Wuhan, China. It was declared as 'Pandemic' by WHO in March 2020 causing a Global Health Crisis.

North-East India: It encompasses of Arunachal Pradesh, Assam, Meghalaya, Nagaland, Manipur, Mizoram, Tripura states of India.

\section{HYPOTHESIS}

$\mathrm{H} 0$-There will be no association between the stress level and selected demographics variables $\mathrm{H} 1$ - There will be an association between stress level and selected demographic variables.

\section{ASSUMPTIONS}

1. All nursing faculties are taking virtual classes during the Covid-19 pandemic.

2. Most of the Nursing faculties are using virtual classes for the first time as a teaching method.

3. Nursing faculties are having stress in adopting a new method of teaching i.e., virtual teaching

\section{INCLUSION CRITERIA}

1. Faculties of Nursing Colleges of North Eastern States of India

2. Nursing faculties who are taking virtual classes during Covid 19 pandemic

\section{EXCLUSION CRITERIA}

Nursing faculties who are not taking virtual classes.

\section{RESEARCH METHODOLOGY}

Target Population: Nursing Faculties of INC Recognized Nursing Colleges of North-East India.

Sample Size: 56 Nursing faculties from selected Nursing colleges of North-East India.

Data Collection: Non-Probability Sampling Convenience sampling technique was used. The information was collected with the help of online google form that includes demographic questionnaires and structured Perceived Stress Scale.

\section{Descriptions about Tools}

Two Tools were used for data collection:

Tool 1: Demographic Data: Age, Marital status, Qualification, Total year of employment, Salary per month, how long you are using virtual teaching, Previous experiences of Virtual teaching and Duration of classes taken in a week

Tool 2. Perceived Stress Scale, PSS-10 (Perceived stress scale) a standardized tool for measuring of stress. The ten questions in this scale ask the participants about their feelings and thoughts during the last month. 


\section{DATA ANALYSIS}

The collected data were analysed using descriptive and inferential statistics to find out the level of stress and to find out the association between stress level and selected sociodemographic variables.

\section{Section A: Description of frequency and percentage distribution of Nursing Faculties by socio- demographic variables}

\begin{tabular}{|c|c|c|c|c|}
\hline $\begin{array}{l}\text { S. } \\
\text { No }\end{array}$ & $\begin{array}{l}\text { Socio- demographic } \\
\text { variable }\end{array}$ & Variable & Frequency & $\begin{array}{l}\text { Percentage } \\
\text { distribution } \\
(\%)\end{array}$ \\
\hline 1 & Age (years) & $\begin{array}{l}25-35 \\
36-45 \\
46-55 \\
56-65\end{array}$ & $\begin{array}{l}46 \\
7 \\
3 \\
0\end{array}$ & $\begin{array}{l}82.1 \% \\
12.5 \% \\
5.4 \% \\
0 \%\end{array}$ \\
\hline 2 & Gender & \begin{tabular}{|l} 
Male \\
Female \\
Transgender
\end{tabular} & $\begin{array}{l}1 \\
55 \\
0\end{array}$ & $\begin{array}{l}1.8 \% \\
98.2 \% \\
0 \%\end{array}$ \\
\hline 3 & Marital status & $\begin{array}{l}\text { Married } \\
\text { Unmarried } \\
\text { Divorce } \\
\text { Widow }\end{array}$ & $\begin{array}{l}29 \\
27 \\
0 \\
0\end{array}$ & $\begin{array}{l}51.8 \% \\
48.2 \% \\
0 \% \\
0 \%\end{array}$ \\
\hline 4 & Qualification & $\begin{array}{l}\text { B.SC(Hons) Nursing } \\
\text { Post basic B.Sc.Nursing } \\
\text { M.Sc. Nursing } \\
\text { M. Phil } \\
\text { PhD } \\
\text { Doctorate }\end{array}$ & $\begin{array}{l}14 \\
0 \\
41 \\
0 \\
0 \\
1\end{array}$ & $\begin{array}{l}25 \% \\
0 \% \\
73.2 \% \\
0 \% \\
0 \% \\
1.8 \%\end{array}$ \\
\hline 5 & $\begin{array}{l}\text { Total year of } \\
\text { experience }\end{array}$ & $\begin{array}{l}\text { Less than } 5 \text { years } \\
5-10 \text { years } \\
\text { More than } 10 \text { years }\end{array}$ & $\begin{array}{l}26 \\
19 \\
11\end{array}$ & $\begin{array}{l}46.4 \% \\
33.9 \% \\
19.6 \%\end{array}$ \\
\hline 6 & Job position & $\begin{array}{l}\text { Tutor } \\
\text { Assistant Professor } \\
\text { Associate Professor } \\
\text { Professor }\end{array}$ & $\begin{array}{l}31 \\
19 \\
4 \\
2\end{array}$ & $\begin{array}{l}55.4 \% \\
33.9 \% \\
7.1 \% \\
3.6 \%\end{array}$ \\
\hline 7 & Type ofemployment & $\begin{array}{l}\text { Private } \\
\text { State Government Central } \\
\text { Government }\end{array}$ & $\begin{array}{l}51 \\
4 \\
1\end{array}$ & $\begin{array}{l}91.1 \% \\
7.1 \% \\
1.8 \%\end{array}$ \\
\hline 8 & Salary per month & \begin{tabular}{|l|}
$<25,000$ \\
$25,100-50,000$ \\
$50,100-75,000$ \\
$75,100-1,00,000$ \\
$>1,00,000$
\end{tabular} & $\begin{array}{l}27 \\
21 \\
2 \\
5 \\
1\end{array}$ & \begin{tabular}{|l|}
$48.2 \%$ \\
$37.5 \%$ \\
$3.6 \%$ \\
$8.9 \%$ \\
$1.8 \%$ \\
\end{tabular} \\
\hline 9 & $\begin{array}{l}\text { How long youare } \\
\text { usingvirtual teaching }\end{array}$ & $\begin{array}{l}\text { Less than 3-months 3-6 months } \\
\text { Greater than } 6 \text { months }\end{array}$ & $\begin{array}{l}11 \\
16 \\
29\end{array}$ & $\begin{array}{l}19.6 \% \\
28.6 \% \\
51.8 \%\end{array}$ \\
\hline 10 & $\begin{array}{l}\text { Previous experience of } \\
\text { virtual teaching }\end{array}$ & Yes No & $\begin{array}{l}23 \\
33\end{array}$ & $\begin{array}{l}41.1 \% \\
58.9 \%\end{array}$ \\
\hline
\end{tabular}




\begin{tabular}{|l|l|l|l|l|}
\hline 11 & Duration of class taken & Less than 3 hours 3-6 hours & 6 & $10.7 \%$ \\
& in a week & Greater than 6 hours & 29 & $51.8 \%$ \\
& & & 21 & $37.5 \%$ \\
\hline
\end{tabular}

Table-A depicted that frequency \& percentage distribution of age, gender, marital status, qualification, total year of experience, job position, type of employment, salary per month, how long they are using virtual teaching, previous experience of virtual teaching, duration of virtual classes in a week.

Section B: Association between selected socio-demographic variables \& stress score.

\begin{tabular}{|c|l|c|l|l|}
\hline S.no. & Socio-demographicvariables & $\begin{array}{l}\text { Degree of } \\
\text { freedom }(\mathbf{d f})\end{array}$ & $\begin{array}{l}\text { Chi squarevalue } \\
\text { (calculated value) }\end{array}$ & $\begin{array}{l}\text { Chi squarevalue } \\
\text { (Table value) }\end{array}$ \\
\hline 1. & Age & 4 & 2.976 & 9.488 \\
\hline 2. & Marital status & 2 & 5.135 & 5.991 \\
\hline 3. & Qualification & 4 & 1.143 & 9.488 \\
\hline 4 & Total year of experience & 4 & 3.974 & 9.488 \\
\hline 4 & Job position & 6 & 3.742 & 12.592 \\
\hline 6. & Type of employment & 4 & 1.342 & 9.488 \\
\hline 7. & Salary per month & 8 & 6.341 & 15.507 \\
\hline 8. & $\begin{array}{l}\text { How long you are using } \\
\text { virtual teaching }\end{array}$ & 4 & 3.161 & 9.488 \\
\hline 9. & Weekly duration ofvirtual teaching & 4 & 7.571 & 9.488 \\
\hline 10. & $\begin{array}{l}\text { Previous experience of virtual } \\
\text { teaching }\end{array}$ & 2 & 2.388 & 5.991 \\
\hline
\end{tabular}

Table B depicted that no association between any of the selected socio demographic variables \& stress score as calculated value of chi square is less than table value of chi square for each socio-demographic variable.

Section C: Description of stress level among Nursing faculties

\begin{tabular}{|c|c|c|c|c|c|}
\hline & & Stres & & & \\
\hline & & Frequency & Percent & Valid Percent & \begin{tabular}{|l} 
Cumulative \\
Percent
\end{tabular} \\
\hline Valid & Low stress & 8 & 14.3 & 14.3 & 14.3 \\
\hline & Moderate stress & 45 & 80.4 & 80.4 & 94.6 \\
\hline & High stress & 3 & 5.4 & 5.4 & 100.0 \\
\hline & Total & 56 & 100.0 & 100.0 & \\
\hline
\end{tabular}

Table $\mathrm{C}$ depicted that frequency \& percentage distribution of stress level among Nursing faculties. depicted that out of 56 samples, $8(14.3 \%)$ have low stress, $45(80.4 \%)$ havemoderate stress \& $3(5.4 \%)$ have high stress. 


\section{CONCLUSION}

The findings of the study illustrated that most of the nursing faculty $(80.4 \%)$ have moderate level of stress, $14.3 \%$ of nursing faculty have low stress level and $5.4 \%$ of nursing faculty have high stress. The study also revealed that there is no association between selected socio-demographic variables and stress level.

\section{REFERENCES}

[1] https://www.un.org/en/coronavirus/act-accelerator

[2] Pourghaznein T, Saveghi H, Shariatinejad K (2015). Effect of e-learning, lectures, and role playing on nursing students' knowledge acquisition, retention and satisfaction. Pubmed.gov.2015 Jan ; 29 : 162. Available from : https://pubmed.ncbi.nlm.nih.gov/26000257/.UN. Act together to End COVID-19. Available from : https://www.un.org/en/coronavirus/actaccelerator.

[3] Sheroun.D wankhar.DD,Devrani.A, pv.L, Gitaes, chatterjee.k A student to assess the perceived stress and coping strategies among B.sc.Nursing students of selected colleges in Pune during covid-19 pandemic Lockdown .IJSHR.2020 June;5(2):1-9.
[4] Guan J W, Ni - Y Z, Zhong S N, Liang WH, Oa. Q. C, He. X. J (2020). Clinical characteristics of coronavirus disease 2019 in China. N Engl J Med. 2019; 382:1268.Available from: https://www.ncbi.nlm.nih.gov/pmc/articles/PMC7092819/?report=reader.

[5] Roy D, Tripathy S, Kar K S, Sharma N, Verma K S, Kaushal V (2020). Study of knowledge, attitude, anxiety and perceived mental health care need in Indian population during COVID-19 pandemic. Asian J Psychiatry. 2020 June; 51:102083. Available from https://www.ncbi.nlm.nih.gov/pmc/articles/PMC7139237/.

[6] UNESCO. 290 million students out of school due to COVID-19. Available from https://en.unesco.org/news/290-million- students-out-school-duecovid-19-unesco- releases-first-global-numbers-and-mobilizes.

[7] Ramona ,maile,catri, Jvano, Mena, Erin ,et. Al, faculty readiness for online crisis teaching .1st. EJTE: European: 2020. 523-1.

[8] Maclntyre P.D,Gnegersen.T, Mercur.s. Language teacher's coping strategies during the covid-19 conversion to online teaching : correlations with stress , wellbeing \& negative emotions. PMC. 2020 Nov;94.

[9] Sreevani R. A guide to mental health psychiatry nursing.4th.NEW DELHI, London,Panama: JAYPEE; 2018.323-4. 